\title{
Blóðsegarek til lungna hjá unglingsstúlku - sjúkratilfelli
}

\section{Sonja \\ Baldursdóttir ${ }^{3}$ \\ læknir \\ Bjarni Torfason ${ }^{1,2}$ \\ sérfræðingur í hjarta- og brjóstholsskurðlækningum}

\section{Gunnlaugur}

Sigfússon ${ }^{1,3}$

sérfræðingur

hjartasjúkdómum barna

Kolbrún

Benediktsdóttir ${ }^{1,2}$

sérfræðingur í myndgreiningu

\section{Ragnar \\ Bjarnason $^{1,3}$ \\ Sérfræðingur \\ innkirtlasjúkdómum barna}

Lykilorð: tölvusneið̋mynd, getnađarvarnarpilla, blóðpynning, skurðaðgerð.

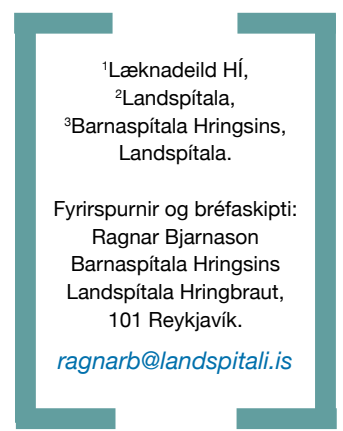

\section{Ágrip}

Blóðsegarek til lungna er sjaldgæf orsök brjóstverkja hjá unglingum og enn sjaldgæfari hjá börnum. Einkenni geta líkst algengum kvillum, svo sem lungna- eða fleiðrubólgu og pví mikilvægt að hafa pau í huga til pess að ekki verði töf á greiningu. Yfirleitt er einn áhættupáttur til staðar, ýmist áunninn eða meðfæddur.

Ekki eru til stöðluð ferli fyrir greiningu blóðsegareks til lungna hjá börnum og unglingum en stuðst er við svipaðar rannsóknir og hjá fullorðnum. Tölvusneiðmyndun af lungnaæðum með skuggaefni (spiral CT angio) er mest notaða aðferðin til greiningar á blóðsegareki til lungna. Meðferð felst í blóðpynningu og pegar pörf krefur er gerð skurðaðgerð til að fjarlægja blóðsegann.

Lýst er blóðsegareki til lungna hjá unglingsstúlku sem var í bráðri lífshættu par sem blóðseginn takmarkaði blóðflæði verulega. Í bráðaskurðaðgerð tókst að fjarlægja blóðsegann í tæka tíð.

\section{Sjúkrasaga}

17 ára stúlka kom á bráðamóttöku barna eftir að hafa verið óglatt og með verki í brjóstkassa í tvær vikur. Í fyrstu hafði ógleðin verið meiri, en síðustu daga fyrir komu hafði verkurinn farið versnandi. Verknum lýsti hún sem sting í bringu sem versnaði við djúpa öndun og litla áreynslu. Auk pess fann hún fyrir mæði og hröðum hjartslætti og hafði ekki getað sótt skóla í nokkra daga vegna pessara einkenna.

Hjá heimilislækni hafði hún verið send í almennar blóðprufur sem voru eðlilegar og pungunarpróf var neikvætt. Tveim dögum fyrir innlögn leitaði hún á bráđamóttöku barna og var talin vera með magabólgur eða bakflæði. Hún var sett á sýruhemlandi lyf sem sló á ógleðina en brjóstverkurinn fór versnandi.

Stúlkan hafði fengið mígreni en var annars hraust og tók engin lyf nema Mercilion getnaðarvarnartöflu síðastliðið hálft ár.

Við skoðun bar stúlkan sig vel en var föl og andstutt. Hún vó 56 kg, líkamshiti mældur í holhönd var $36,3^{\circ} \mathrm{C}$, blóðprýstingur 98/65 mm kvikasilfurs, hjartsláttur 110 slög/mínútu og súrefnismettun $98 \%$. Útlimir voru kaldir átöku og áberandi blámi. Hjartalínurit sýndi sinus takt, eðlilegan öxul og viðsnúna T-takka í hægri brjóstleiðslum (V1-V3) sem er eðlilegt hjá börnum og unglingum. Röntgenmynd af lungum var eðlileg. Blóðhagur, $\mathrm{Na}$, K, kreatínín, CRP, blóðsykur, lifrarpróf og hjartaensímin CK-MB og trópónín-T, var innan marka en D-dímer var hækkaður, $18 \mathrm{mg} / \mathrm{L}$ (viðmiðunargildi <0,50 mg/L). Hjartaómskoðun sýndi eðlilega byggingu hjartans og engin merki um gollurshúsbólgu. Hægri slegill var stækkaður og var pað talið vegna prýstingsálags par sem prýstingur slegils var metinn hækkaður við óbeina mælingu á príblöðkulokuleka. Vaknaði við pað grunur um blóðsegarek til lungna og var pví gerð tölvusneiðmynd með skuggaefni af brjóstholi. Rannsóknin sýndi stóran söðulblóðsega sem hefti blóðflæði til beggja lungna (mynd 1). Stúlkan var flutt á gjörgæsludeild til undirbúnings fyrir opna hjartaskurðaðgerð. Pegar komið var á skurðstofu versnaði ástand stúlkunnar skyndilega, súrefnismettun féll í 77\%, en blóðprýstingur var viðunandi, um 90 mm kvikasilfurs. Pegar opnað var inn í gollurshús kom í ljós mjög stórt hjarta, panin hægri gátt og hægri slegill. Meginlungnaslagæð var opnuð eftir að hjartalungnavél hafði tekið yfir starfsemi hjarta og lungna og pá kom í ljós um $20 \mathrm{~cm}$ langur og sver blóðsegi, 2,0-2,5 cm í pvermál (mynd 2). Blóðseginn lá yfir greiningu lungnaslagæðar til hægra og vinstra lunga og fyllti pær nær alveg á löngum kafla. Blóðseginn var fjarlægður, blóð-

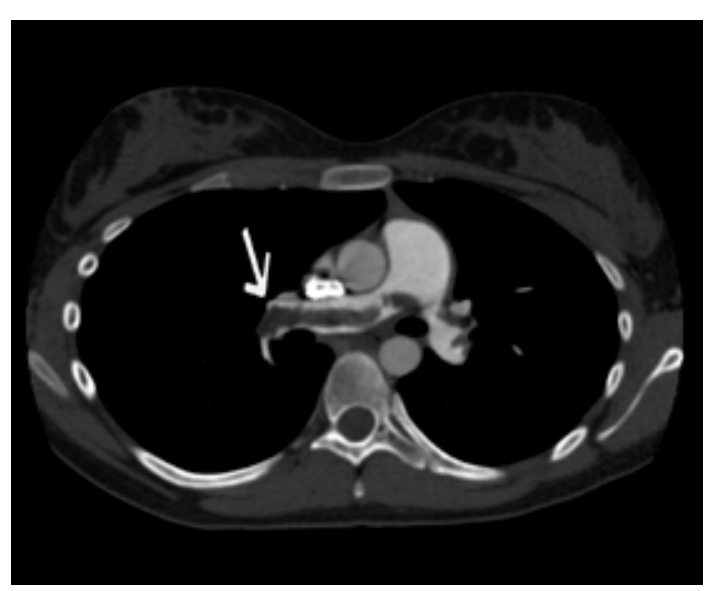

Mynd 1. Tölvusneiðmynd með skuggaefni af brjóstholi sýndi söðulblóðsega í lungnaslagæð. 


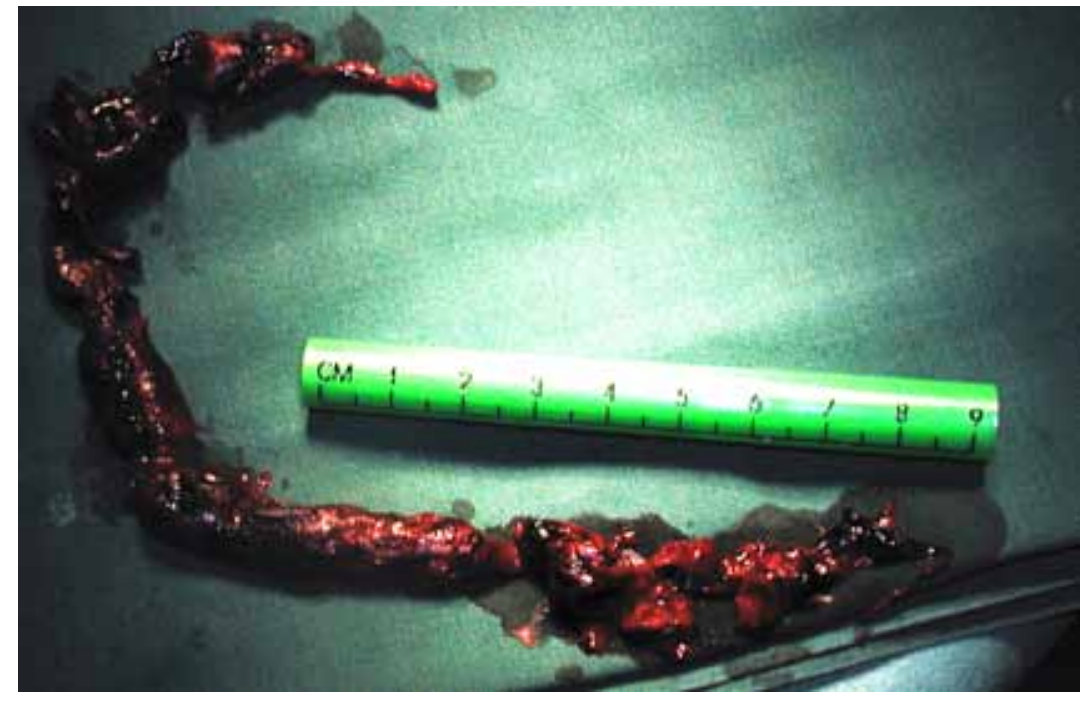

Mynd 2. Blóðseginn reyndist um $20 \mathrm{~cm}$ langur og 2-2,5 cm í pvermál.

flæði hleypt á kerfið að nýju og hjartalungnavélin stöðvuð. Ljóst var að aðgerðin hefði ekki mátt tefjast lengur par sem blóðrás til lungna var að lokast. Stúlkan jafnaði sig hratt á gjörgæslu og var flutt á barnaskurðdeild sólarhring eftir aðgerð. Blóðpynnandi meðferð hófst með enoxaparíum (Klexan) $20 \mathrm{mg}$ undir húð daglega. Pegar dren höfðu verið fjarlægð tveimur dögum eftir aðgerð var skipt yfir í heparín 5000 IE x 4 í æð og blóðpynning með warfaríni (Kóvar) hafin. Pegar meðferðargildum var náð (INR 2-3) var heparínmeðferð hætt. Stúlkan jafnaði sig vel og útskrifaðist heim viku eftir aðgerðina. Ýtarlegar rannsóknir voru gerðar á segahneigð en engin orsök fannst önnur en hugsanlega getnaðarvarnartaflan.

Stúlkan leitaði aftur á bráðamóttöku barna 12 dögum eftir útskrift og hafði pá verið með verk í ofanverðum kvið í sólarhring sem versnaði við hreyfingar. Hún var hitalaus, hjartsláttur 98 slög/ mínútu, blóðprýstingur 104/65 mm kvikasilfurs og súrefnismettun var $99 \%$. Við skoðun komu fram eymsli ofanvert í kvið og yfir lifrarstað en blóðprufur, par á meðal lifrar- og brisprufur, voru eðlilegar. INR mældist innan meðferðarmarka. Lungnamynd sýndi hins vegar mjög stórt hjarta og á tölvusneiðmynd af brjóstholi sást mikill vökvi í gollurshúsi, $5 \mathrm{~cm}$ par sem mest var. Morguninn eftir fór stúlkan í aðgerð í svæfingu og var dren lagt inn í gollurshús með opinni tækni til að tæma út vökva eftir að blóðpynningu hafði verið snúið við með prothromplex og K-vítamíni. Í aðgerðinni voru tæmdir út $700 \mathrm{ml}$ og komu $280 \mathrm{ml}$ í viðbót í dren sem var skilið eftir. Eftir aðgerðina var blóðpynning hafin aftur með enoxaparíum 60 mg x 2 undir húo og warfarínmeðferð hafin að nýju eftir að dren var fjarlægt tveimur dögum seinna. Stúlkan útskrifaðist premur dögum eftir aðgerð og var fylgt eftir með hjartaómskoðunum dagana á eftir og náði hún sér að fullu. Talið var að vökvasöfnunin í gollurshúsi stafaði af bólguviðbragði eftir fyrri aðgerð (postpericardiotomy syndrome).

Blóðpynningarmeðferð með warfaríni var haldið áfram í eitt ár og síðan hjartamagnýl. Stúlkunni var ráðið frá pví að nota getnaðarvarnartöflur og fékk ráðleggingar til að draga úr hættu á endurkomu blóðsega í djúpar bláæðar.

\section{Umræður}

Greint er frá mjög sjaldgæfri en lífshættulegri orsök fyrir brjóstverkjum hjá börnum og unglingum. Greining blóðsegareks til lungna er oft erfið en vegna pess hve hættulegt fyrirbærið er og sjaldgæft hjá pessum aldurshópi, er mikilvægt hafa pessa greiningu í huga.

Brjóstverkur er algeng kvörtun hjá börnum og unglingum en yfirleitt er ekki um alvarlega orsök að ræða. Раð parf hins vegar nákvæma sögu og skoðun til að greina pá frá sem purfa nánari uppvinnslu. Prátt fyrir ýtarlegar rannsóknir finnst ekki undirliggjandi orsök brjóstverkja hjá börnum og unglingum í 28-45\% tilfella. ${ }^{1}$ Pótt hjartasjúkdómur sé pað sem margir óttast mest er pað sjaldgæf orsök brjóstverkja hjá börnum (færri en 5\% tilfella). Algengara er að verkir tengist stoðkerfi, öndunarfærum eða meltingarfærum. ${ }^{1}$

Stoðkerfisvandamál valda brjóstverkjum hjá börnum í 15\% tilfella ${ }^{2}$ og unglingum í 31\% tilfella. ${ }^{3}$ Pau geta stafað af áverka eða ofreynslu við ípróttir. Í 2-11\% tilvika stafa brjóstverkir hjá börnum og unglingum frá öndunarfærum, oftast frá astma, en einnig eru aðrar pekktar skýringar, svo sem lungnabólga, fleiðruvökvi og loftbrjóst. Oföndun og kvíði geta einnig valdið brjóstverkjum sem og vandamál í meltingarfærum, til dæmis vélindabakflæði. Sjaldgæft er að brjóstverkir hjá börnum og unglingum stafi frá hjarta og æðakerfi, ólíkt pví sem gerist hjá fullorðnum. Gollurshúsbólga (pericarditis) og blóðsegarek til lungna eru pó meðal pekktra orsaka.

Einkenni og áhættupættir blóðsegareks til lungna eru ekki eins vel pekktir hjá börnum og hjá fullorðnum. Hjá börnum geta einkennin oft á tíðum líkst einkennum algengari sjúkdóma og getur pað valdið töf á greiningu. Í rannsóknum er meðaltími frá upphafi einkenna til greiningar ein vika eða á bilinu 1-21 dagur.

Aftursýn rannsókn sem skoðaði innlagnir unglinga á sjúkrahús yfir 15 ára tímabil sýndi að nýgengi blóðsegareks til lungna var 78 af hverjum 100.000 unglingum sem lögðust inn. Stúlkur reyndust tvöfalt fleiri en drengir í pessari rannsókn. Algengustu einkennin voru brjóstverkir, mæði, hósti og blóðhósti. Aðal áhættupættirnir 
voru notkun getnaðarvarnartaflna og fóstureyðing hjá stúlkum (75\%) og slys/áverkar hjá drengjum $(67 \%)^{4}$

Flest börn sem fá blóðsegarek til lungna hafa að minnsta kosti einn áhættupátt. Áunnir áhættupættir eru svipaðir hjá börnum og fullorðnum, sá algengasti hjá börnum er djúpbláæðaleggir. ${ }^{5}$ Algengustu meðfæddu áhættupættir fyrir segamyndun eru stökkbreytingar í factor V (factor V Leiden) og prothrombin (prothrombin 20210 A) ${ }^{6}$

Ekki fundust merki um meðfædda segahneigð hjá stúlkunni og var notkun getnaðarvarnarpillu talinn hennar eini áhættupáttur.

Sýnt hefur verið að samsettar getnaðarvarnarpillur auka líkur á myndun blóðsega. Áhættan er mest fyrstu mánuðina eftir að meðferð hefst og eftir pví sem estrógenmagnið er meira. ${ }^{7}$

Engin sértæk greiningarferli hafa verið próuð fyrir börn og pau sem notuð eru fyrir fullorðna hafa ekki verið skoðuð miðað við forspárgildi í börnum.

D-dímer er oft notaður sem hluti af greiningarferli blóðsegareks til lungna hjá fullorðnum par sem rannsóknir hafa sýnt að mælingin hefur 96,4\% næmi og að neikvætt forspárgildi er 99,6\% hjá fullorðnum. ${ }^{8}$ Engar stórar rannsóknir hafa skoðað gagnsemi D-dímer við greiningu blóðsegareks til lungna hjá börnum.

Lungnaæðamyndataka hefur verið talin gullstika í greiningu blóðsegareks til lungna og sjást pá eyður eða pverstopp í skuggaefnisfyllingu. ${ }^{5}$ Rannsóknin er hins vegar ífarandi og dýr og pví ekki mikið notuð núorðið. Í dag er oftast stuðst við tölvusneiðmyndatöku af lungnaæðum með skuggaefni (spiral CT angio). Hún tekur skamman tíma og gefur upplýsingar um blóðsegarek og mögulega fylgikvilla pess, svo sem drep í lungnavef. Einnig getur rannsóknin greint aðrar skýringar, svo sem lungnabólgu og bólgur í gollurshúsi. Ókostir rannsóknarinnar eru peir að sjúklingurinn verður fyrir umtalsverðri geislun og nota parf skuggaefni í æð sem hentar ekki peim sem eru með ofnæmi fyrir skuggaefni eða skerta nýrnastarfsemi. Stöku sinnum er gert innöndunarblóðflæðiskann af lungum en niðurstaða pess er oft ekki afgerandi og háð peim sem les úr rannsókninni.

Stúlkan fór í bráðaaðgerð par sem blóðseginn var fjarlægður. Annar kostur er segaleysandi meðferð en deila má um hvort hún hefði komið til greina par sem ástand stúlkunnar var óstöðugt og hratt versnandi.

\section{Heimildir}

1. Selbst SM. Evaluation of chest pain in children. Pediatr Rev 1986; 8: 56-62.

2. Selbst SM, Ruddy RM, Clark BJ, et al. Pediatric chest pain: a prospective study. Pediatrics 1988; 82: 319-23.

3. Pantell RH, Goodman BW, Jr. Adolescent chest pain: a prospective study. Pediatrics 1983; 71: 881-7.

4. Bernstein D, Coupey S, Schonberg SK. Pulmonary embolism in adolescents. Am J Dis Child 1986; 140: 667-71.

5. Van Ommen $\mathrm{CH}$, Peters M. Acute pulmonary embolism in childhood. Thromb Res 2006; 118: 13-25.

6. Lane DA, Mannucci PM, Bauer KA, et al. Inherited thrombophilia: Part 1. Thromb Haemost 1996; 76: 651-62.

7. van Hylckama Vlieg A, Helmerhorst FM, Vandenbroucke $\mathrm{JP}$, et al. The venous thrombotic risk of oral contraceptives, effects of oestrogen dose and progestogen type: results of the MEGA case-control study. BMJ 2009; 339: b2921.

8. Schoepf UJ, Goldhaber SZ, Costello P. Spiral computed tomography for acute pulmonary embolism. Circulation 2004; 109: 2160-7.

\section{Pulmonary embolism in a teenage girl}

Pulmonary embolism is an uncommon but potentially life threatening disease in children and adolescents. The clinical findings can be similar to other more common conditions such as pneumonia. Therefore high level of suspicion is required for early and accurate diagnosis. Most children have at least one underlying risk factor, either inherited or acquired.

Computed tomography is the most widely used method

Baldursdottir S, Torfason B, Sigfusson G, Benediktsdottir K, Bjarnason R.

Pulmonary embolism in a teenage girl. Icel Med $J$ 2011; 97: 97-9.

Key words: computed tomography, $P$-pill, anticoagulation, surgery

Correspondence: Ragnar Bjarnason, ragnarb@landspitali.is in diagnosing pulmonary embolism. Anticoagulation is the mainstay of therapy for pulmonary embolism, however, acute surgery may be recquired for removal of the embolism.

We report a case of pulmonary embolism in a teenage girl with serious circulatory failure where emergency surgery was needed. 